Article

\title{
Rorty, Williams, and Davidson: Skepticism and Metaepistemology
}

\section{Duncan Pritchard * and Christopher Ranalli}

School of Philosophy, Psychology \& Language Sciences, University of Edinburgh, Dugald Stewart Building, Charles Street, Edinburgh, EH8 9AD, UK; E-Mail: c.ranalli@sms.ed.ac.uk

* Author to whom correspondence should be addressed; E-Mail: duncan.pritchard@ed.ac.uk.

Received: 12 June 2013; in revised form: 21 June 2013 / Accepted: 25 June 2013 /

Published: 8 July 2013

\begin{abstract}
We revisit an important exchange on the problem of radical skepticism between Richard Rorty and Michael Williams. In his contribution to this exchange, Rorty defended the kind of transcendental approach to radical skepticism that is offered by Donald Davidson, in contrast to Williams's Wittgenstein-inspired view. It is argued that the key to evaluating this debate is to understand the particular conception of the radical skeptical problem that is offered in influential work by Barry Stroud, a conception of the skeptical problem which generates metaepistemological ramifications for anti-skeptical theories. In particular, we argue that, contra Williams, Rorty's view that Davidson was offering a theoretical diagnosis of radical skepticism can be consistently maintained with his transcendental approach.
\end{abstract}

Keywords: transcendental arguments; radical skepticism; metaepistemological skepticism; theoretical diagnosis; Barry Stroud

\section{Introductory Remarks}

Our goal in this paper is to revisit an important exchange between Richard Rorty [1] and Michael Williams [2] concerning the problem of radical skepticism about the external world (henceforth just 'radical skepticism'). Contra Williams, Rorty was defending the broadly transcendental anti-skepticism put forward by Donald Davidson [3]. Williams, in turn, was urging his own distinctive, Wittgenstein-inspired, response to the problem. 
In order to understand what is going on this debate, and to offer an adjudication, we need to understand the conception of the radical skeptical problem that Williams takes himself to be responding to. To that end, we need to approach our discussion of Rorty and Williams on radical skepticism (and thereby Davidson and the later Wittgenstein) by first considering the skeptical challenge as presented by Barry Stroud [4]. Accordingly, in $\S 1$ we set out Stroud's conception of radical skepticism and the metaepistemological skeptical challenge that results. In §2, we outline Williams's response to these skeptical challenges. In §3, we consider Davidson's broadly transcendental response to the problem of radical skepticism. Finally, in §4, we delve into the details of the debate between Rorty and Williams. Specifically, we argue that it is consistent with Davidson's transcendental response to the problem of radical skepticism that he was also, following Rorty [1], aiming to reveal the philosophical presuppositions that ground that problem. In short, he was also aiming to give what Williams [5] calls a 'theoretical diagnosis' of radical skepticism, contra William's suggestion that he wasn't.

\section{Stroud's Metaepistemological Skepticism}

Radical skepticism consists of a distinctive type of epistemic evaluation regarding a wide class of beliefs of certain kind. In particular, the radical skeptic is engaged in a form of doubt which is wholesale rather specific, and entirely acontextual. Call these skeptical epistemic practices. How should we understand the relationship between skeptical epistemic practices and the everyday epistemic practices which we employ day-to-day in non-philosophical contexts?

On the face of it, there is a stark contrast between the two. For while the skeptical epistemic practices are wholesale, the everyday epistemic practices are markedly piecemeal and local, and while the skeptical epistemic practices are entirely acontextual, the everyday epistemic practices are very sensitive to salient features of the contexts in which epistemic evaluations are undertaken. If this way of thinking about skeptical epistemic practices and their quotidian counterparts is correct, then it puts the radical skeptic at a distinct dialectical disadvantage from the off. For if these two practices of epistemic evaluation are so distinct, then it prompts the natural question of why we can't legitimately prefer the counsel of our everyday epistemic practices to the skeptical alternative. We can put the point this way: if radical skepticism constitutes such a departure from our commonsense practices of epistemic evaluation, then what is to stop us from digging in our intellectual heels and insisting on commonsense over the dubious (on account of its tension with commonsense) philosophy employed by the radical skeptic?

As Stroud [4] famously argued, however, a compelling case can be made for the claim that radical skepticism, even despite its superficial differences with our everyday epistemic practices, nonetheless arises out these very everyday practices. Stroud's argument begins in a familiar fashion with Descartes. Stroud argues that if Descartes is right in thinking that all of our sensory experiences are compatible with dreaming, then we must explain how it is nevertheless possible for us to have knowledge of the external world on the basis of experience, if it is possible at all. For Stroud, following Descartes, this meant that a necessary condition of having experiential knowledge of the external world is to know that one is not dreaming — call this Descartes' condition. Crucially, however, 
Stroud claims that it is hard to see how we might satisfy Descartes' condition. Thus it follows that our knowledge of the external world is brought into question ${ }^{1}$.

Thus far, all of this is entirely in keeping a conception of skeptical epistemic practices as being utterly distinct from everyday epistemic practices. The radical skeptic, it seems, is imposing conditions on knowledge, such as Descartes' condition, which simply would not arise in normal contexts of epistemic evaluation. In normal epistemic contexts, after all, we would never require of an agent before she counted as having perceptual knowledge that she should be able to know that she is not dreaming. The radical skeptic is therefore playing a different epistemic game to the one that we ordinarily play, and hence the onus is on them to offer a defence of their alternative, and contrary to commonsense, system of epistemic evaluation.

Nonetheless, Stroud insists that despite the superficial differences between these two epistemic practices, the skeptical epistemic practices are rooted in our everyday epistemic practices. In particular, he argues that the condition on perceptual knowledge we just saw employed as a route to skepticism - i.e., Descartes' condition - “seems like nothing more than an instance of a familiar commonplace about knowledge.” ([4], p. 24) But this is puzzling, since didn’t we (rightly) just note that our everyday epistemic practices impose no such condition?

For Stroud, however, an epistemic principle can be rooted in our everyday epistemic practices without ever being instantiated in them, and this point is crucial to understanding his proposal. In particular, our everyday epistemic practices are constrained in legion ways by all manner of practical limitations — such as limitations of time, or even simply of imagination - which prevent us from applying the epistemic principles that underlie our everyday epistemic practices in a thorough-going fashion. But if we did, claims Stroud, then we would impose conditions on perceptual knowledge such as Descartes' condition.

So, for example, in our everyday epistemic practices we require of agents if they are to count as having knowledge that they can rule-out certain error-possibilities which are inconsistent with that knowledge. In order to perceptually know that the creature before me is a goldfinch, for instance, I may be required to know that it is not some other type of bird which might plausibly be in the vicinity, such as a goldcrest ${ }^{2}$. Stroud's idea is that what we are witnessing here is a restricted version of Descartes' condition, where the motivation for the restriction is purely the practical limitations which are imposed upon us in ordinary contexts. But suppose we removed those restrictions and applied the epistemic principles in play here in a thorough-going way. Wouldn't we end up implementing Descartes' condition on perceptual knowledge?

Stroud's idea is thus that the skeptical epistemic practices, while superficially distinct from everyday epistemic practices, are nonetheless rooted in everyday epistemic practices, in the sense that they are simply a 'purified' version of those everyday practices-i.e., once we abstract away from the epistemically irrelevant factors such as the practical limitations of time, imagination, and so on, what we are left with are the skeptical epistemic practices. As Stroud ([4], p. 82) famously put it, radical skepticism is a paradox in that rather than being the consequence of contentious theoretical claims it instead falls out of "platitudes we would all accept." If Stroud is right about this, then the tables in the

See ([4], pp. 20-23) for the argument, and [6] for a restatement of the basic structure of the argument.

2 This example is, of course, due to Austin [7]. 
skeptical debate have been turned: For we can no longer plausibly argue that the skeptic is enforcing some arcane, remarkable, or implausible requirement on perceptual knowledge. Instead, one is faced with arguing against an epistemic principle which one, along with most, if not all us, adhere to in otherwise normal circumstances. The dialectical advantage thus goes to the skeptic rather than us.

Stroud is not himself a skeptic about our knowledge of the external world. But he has argued that it's not possible to satisfactorily explain how perceptual knowledge of the world is possible (see [8,9]). The reason why this is so should jump off the page. After all, if a necessary condition on perceptual knowledge is just the expression of "platitudes we all accept", and this condition looks unfulfillable, how could we explain how perceptual knowledge of the world is possible to our satisfaction? We couldn't. What we seek as epistemologists is some kind of equilibrium between commonsensical principles and theoretical reasoning. But do we reach that kind of equilibrium if, according to Stroud, we have to reject a "platitude"-something which "seems like nothing more than an instance of a familiar commonplace about knowledge”? No. As Stroud acknowledges, what other conception of knowledge do we have except "what is embodied in those procedures and practices" that we follow in everyday circumstances?

Call this thesis metaepistemological skepticism. It is a specifically metaepistemological form of skepticism in that it is concerned not with the truth of radical skepticism, but rather with the intellectual palatability of anti-skeptical theories. The specific challenge posed by metaepistemological skepticism is not to solve the radical skeptical problem (though that would suffice to deal with the challenge), but rather to demonstrate that an intellectually plausible resolution of that problem is not ruled out tout court.

\section{Williams contra Stroud}

Williams [5] disputes Stroud's claim that skepticism is the product of a principle which can be teased out of our normal epistemic evaluative practices. Against this, Williams proposes that skepticism is instead the product of certain dispensable philosophical commitments. In this fashion, Williams rejects metaepistemological skepticism.

However, in some sense Williams can also be understood as a proponent of metaepistemological skepticism. For he holds that we can't explain how knowledge of the external world is possible to our satisfaction because he denies that there is knowledge of the external world so-called. So rather than thinking of him as a metaepistemological skeptic, it is better to think of him as maintaining that the epistemological question is just a bad one. The question 'how is perceptual knowledge of the external world possible?' is not a question about a kind of knowledge, because he doesn't think there are general kinds of knowledge. There is just nothing there from which a general question could be raised: there is no knowledge of the external world, but not because no one knows that there are tables, people, trees, and the like. Instead, Williams thinks that it's false that "[b]eliefs, in virtue of their contents alone, fall into natural epistemological kinds” ([10], p. 419). Following Williams ([5,10]), call this thesis epistemological realism.

For example, the list we just gave looks like it falls into the 'natural epistemological kind' of knowledge of the external world because it's about tables, trees, and people. But, as Williams asks, what sows the thread between tables, trees, and people, which is sufficient to ask, in general, how we 
could ever come to have that kind of knowledge? The most straightforward answer is 'material objects' and our general means of coming to know about them, which is 'the senses'. But Williams thinks that this answer isn't to the point. What is it about the senses which makes knowledge of people, trees, and tables a bona fide kind of knowledge? According to his diagnosis, it's that what we know through the senses is 'prior' to our other knowledge in the sense that one could know that one is having an experience as of a tree before one without knowing that a tree is before one. In general, for each sensory experience one could have, one could know what the experience is like without knowing something about the world around one. Williams calls this foundationalism, and he thinks this is what skepticism hinges on. Foundationalism, in turn, hinges on the truth of epistemological realism.

Now, it's important to note that Williams isn't trying to solve the problem of the external world in the sense of giving a positive or negative answer to the question 'how is perceptual knowledge of the world possible?' Instead, he gives what he calls a "theoretical diagnosis” of the problem. A theoretical diagnosis would tell us what theoretical commitments the problem of the external world, and its attendant skepticism, are grounded in. Notice that if Williams is right about this - that the problem of the external world presupposes the truth of epistemological realism, a less than commonsensical picture of our epistemological practices - then the burden is shifted back onto the would-be skeptic about the external world. The tables haven't been turned at all ${ }^{3}$.

In an important exchange on the problem of radical skepticism between Rorty [1] and Williams [2], Rorty doesn't question whether or not Williams is right in thinking that a successful resolution to the problem of the external world requires a theoretical diagnosis. Instead, he questions whether Williams has given the right theoretical diagnosis. According to Rorty, Williams fails to appreciate the diagnostic element in Davidson's anti-skeptical work (in particular [3]).

In the next section, we sketch a plausible interpretation of Davidson's anti-skeptical work. Specifically, we suggest that the anti-skeptical element of Davidson's work should be traced back to his version of content externalism, and that with this thesis in hand, Davidson is best understood as providing a transcendental response to the problem of the external world. But, in the fourth and final section, we also suggest that there is no obvious tension between reading Davidson as Rorty does - i.e., as providing a theoretical diagnosis of the problem of the external world - and as we do-i.e., as providing a transcendental response to the problem of the external world.

\section{Davidson on Radical Skepticism}

Key to Davidson's anti-skepticism is the notion of radical interpretation. Building on earlier work on radical translation undertaken by W. V. O. Quine [14], Davidson conceives of radical interpretation as taking place when one interprets a speaker without reliance on any prior knowledge of either the speaker's beliefs or the meanings of the speaker's utterances. The importance of radical interpretation for Davidson's work is that he holds that it is a necessary truth that any content-bearing sentence is interpretable under these epistemological conditions.

Radical interpretation faces a problem, however, which is that one cannot assign a meaning to a speaker's utterances without knowing what the speaker believes, and one cannot identify the speaker's

3 For a recent survey of contemporary treatments of radical skepticism, see [11]. For more specifically on Stroud's contribution to our understanding of the skeptical problem, see [12,13]. 
beliefs without knowing what her utterances mean. So, for example, if one does not already have a purchase on a speaker's beliefs, then how is one to interpret an utterance of a sentence (in the vicinity of a rabbit, say) as being a sentence with a particular content (such as, 'that's a rabbit')? But if one cannot assign meanings to the speaker's utterances, then how is one to determine, in the conditions of radical interpretation, what the speaker's beliefs are? One is thus apparently stuck within an interpretative circle.

Davidson's resolution of this problem is to appeal to the principle of charity. While this is never given a particularly precise rendering, roughly it instructs the interpreter to treat the speaker as having mostly true beliefs (by the interpreter's lights anyway). It's clear from how Davidson applies this principle that there are two key dimensions to applications of charity. On the one hand, interpreting a speaker as charity demands will tend to lead to an interpretation which treats the speaker as having a coherent — or, at least, consistent anyway — set of beliefs. On the other hand, charity will tend to lead to an interpretation which treats the speaker's beliefs as being correctly about the objects in the speaker's immediate environment which the speaker is interacting with ${ }^{4}$.

By using the principle of charity in this fashion, we have a way out of the interpretative circle just noted. The radical interpreter is using her beliefs as a way of assigning beliefs to the speaker, and in doing so is able to assign meanings to her utterances. So, for example, if the speaker is observed uttering sentences in the vicinity of a certain object, such as a rabbit, then by treating the speaker as having mostly true beliefs (by the interpreter's lights anyway), one will have a way of ascribing a meaning to the speaker's utterances, such as 'that's a rabbit'. Of course, the ascription will be defeasible, and in time the radical interpreter may settle on a very different interpretation of the speaker's utterances. But at least this application of the principle of charity enables the radical interpreter to coherently begin the project of radical interpretation ${ }^{5}$.

On the face of it, the principle of charity offers us no particular respite from the radical skeptical challenge. That it may be methodologically necessary for the project of radical interpretation to treat a speaker's beliefs as mostly true by our lights does not in itself give us any more reason to think that the speaker's beliefs are in fact true than it does for thinking that our beliefs are true. Indeed, the radical skeptic might well concede the methodological necessity of the principle of charity to the project of radical interpretation while nonetheless insisting that, for all that, one's beliefs could be mostly false.

Exactly how Davidson bridges the argumentative gap from a 'subjective' application of the principle of charity in the project of radical interpretation to the claim that "belief is in its nature veridical” ([3], p. 314) is controversial, as we will see. Nonetheless, it is clear that at one point in the development of his thinking at least Davidson held that he could bridge this gap by appeal to what he refers to as an omniscient interpreter. While the idea of an omniscient interpreter made brief appearances in earlier work— such as [18] and [19]—let us focus on its clearest expression in [3].

4 In later work — e.g., ([15], p. 211)—Davidson referred to these two elements of the principle of charity as, respectively, the principles of coherence and correspondence.

5 One question we might raise at this juncture is whether it is the principle of charity, specifically, which is required for the project of radical interpretation, and not some weaker principle. One candidate in this regard, offered by [16], is the 'principle of humanity'. Very roughly, this directs us to interpret speakers in such a way as to make them intelligible, but does not (explicitly, anyway) demand that we interpret them in such a way as to maximize truth in their beliefs. See also [17]. For reasons of space, we set aside this question in what follows. 
At one juncture in this text Davidson is occupied with the thought that a speaker and an interpreter could make sense of each other's utterances on the basis of shared, but false, beliefs. Clearly, Davidson cannot deny that this is a possibility. Nonetheless, he insists that this cannot be the norm, and to explain why in a famous passage he introduces the idea of an omniscient interpreter:

For imagine for a moment an interpreter who is omniscient about the world, and about what does and would cause a speaker to assent to any sentence in his (potentially unlimited) repertoire. The omniscient interpreter, using the same method as the fallible interpreter, finds that fallible interpreter largely consistent and correct. By his own standards, of course, but since they are objectively correct, the fallible interpreter is seen to be largely consistent and correct by objective standards ([3], p. 317).

Since the omniscient interpreter, whose beliefs are by definition true, would in interpreting us find most of our beliefs true as well, so we can be assured, goes the argument, that most of our beliefs are true too. Clearly, if this line of argument works, then Davidson has the argumentative bridge that he needs to go from the methodological necessity of the principle of charity in the project of radical interpretation to the anti-skeptical claim that belief is in its nature veridical. But does it work?

The short answer is that it probably doesn't. One difficulty that has been raised is the very idea of an omniscient interpreter being bound to use the principle of charity in making sense of our utterances. For although we can understand why non-omniscient creatures such as ourselves might need to employ the principle of charity in interpreting the utterances of others, why would an omniscient creature be so restricted? In particular, why would a creature who is omniscient about 'what does and would cause a speaker to assent to any sentence in his (potentially unlimited) repertoire' need to rely on a methodological principle like the principle of charity in making sense of a speaker's utterances? After all, a core part of the reason why we need to appeal to this principle is our supposed lack of epistemic access, in the context of radical interpretation anyway, to what is causing the speaker's utterances ${ }^{6}$.

Moreover, even if we grant that the omniscient interpreter will ascribe mostly true beliefs to us, this still seems consistent with there being a significant mismatch in how we conceive of our own situation and how the omniscient interpreter, from its epistemically elevated viewpoint, conceives of it. In short, that our beliefs are mostly true does not in itself guarantee that we are not in some fundamental respect in error. Here is Michael Williams on this point:

[...] what possible reason do we have for supposing that the interpretation available to the omniscient interpreter, through his knowledge of the real causes of our beliefs, matches the self-understanding that we generate through exploring the inferential relationships between beliefs in our system from the 'inside'. For example, if we were brains in vats, kept ignorant of our fate and hooked up to some kind of speaking apparatus, the omniscient interpreter would take our utterances to be about events in the computer that controls our stimulated sensory input, though presumably we would not ([20], p. 190).

6 See ([20], §5) for a pointed critical discussion of the notion of an omniscient interpreter along these lines. See also [21] for a related critical discussion about the very idea of an omniscient interpreter as Davidson's describes him engaging in a genuine project of interpretation. (Note that in the background here is the question of whether on Davidson's view there is any fact of the matter about someone's mental states, since if this is the case then of course the omniscient interpreter will need to engage in a project of interpretation, even despite his epistemically privileged position. On this point see ([22], §2)). 
While, as noted above, Davidson's proposal is not meant to guarantee us widespread knowledge, it is meant to exclude the kind of fundamental error at issue in a BIV case. If it turns out that it doesn't even exclude this possibility, then its anti-skeptical potential is severely blunted.

A third kind of worry about the appeal to the notion of an omniscient interpreter is that it is somehow question-begging. One version of this charge is put forward by Kirk Ludwig. He argues that insofar as we can make sense of the idea of an omniscient interpreter, then we should also be able to make sense of an 'omnignorant' interpreter, where this is someone who is "mostly wrong about the world.” He writes:

Combining this assumption with the assumption that all language speakers must potentially be in communication with each other, and the impossibility of communication without massive agreement, we can conclude that most of our beliefs are false. As we might put it: true belief is possible only against a background of largely false belief ([23], p. 327).

By appealing to the notion of an omnignorant interpreter rather than an omniscient interpreter we can thus, by parity of reasoning, generate the exact opposite conclusion to the one that Davidson was trying to motivate. In order for the omniscient interpreter argument to work, it is thus essential that we have a basis for rejecting the possibility of an omnignorant interpreter. But as Ludwig points out, if we have such grounds, then there is no need for the appeal to an omniscient interpreter, since we'd already have an assurance that we can’t be massively mistaken about the world ${ }^{7}$.

Given how problematic Davidson's appeal to the notion of an omniscient interpreter is, we might reasonably ask whether he can do without it in his argument. In this regard it is notable that where Davidson does appeal to this notion it is usually as part of a dialectical move that does not seem to be significantly weight-bearing in terms of the argument as whole. In [3], for example, the appeal to the idea of an omniscient interpreter comes after the main thread of argument, as if it is merely an illustration of that argument rather than an extension of it. Moreover, by [26] we have him saying that he regrets ever appealing to the notion of an omniscient interpreter and conceding that such an appeal "does not advance my case". He goes on to remark that if "the case can be made with an omniscient interpreter, it can be made without, and better.” ([26], p. 192) Accordingly, our focus in understanding the motivation for Davidson's anti-skepticism should not be side-tracked by the problems that face his appeal to an omniscient interpreter ${ }^{8}$.

But if the argumentative bridge needed to get from Davidson's use of the principle of charity to his anti-skepticism does not come from the appeal to the omniscient interpreter, then where does it come from? The answer lies in Davidson's commitment to a form of content externalism.

In order to understand Davidson's particular variant of content externalism, we first need to say a little about his conception of triangulation ${ }^{9}$. According to Davidson, triangulation involves a causal

7 For another variant of the charge that Davison's argument, if successful, proves too much, see [24]. Cf. ([25], p. 155).

8 The three objections to Davidson's appeal to the notion of an omniscient interpreter offered here far from exhaust the critical literature in this regard. For example, one prominent critical line —offered by [27] _ contends that Davidson is committed to the implausible conclusion that such an interpreter actually exists. For another important critical discussion of the notion of an omniscient interpreter, see [28]. See also [29] and footnote 8.

9 Davidson defends (versions of) triangulation in a number of places. For a particularly explicit discussion of this notion, see [30]. Cf. [31,32]. 
nexus involving two subjects and an object in a common physical environment. Triangulation occurs when both creatures react to that object and then react in turn to each other's reactions ${ }^{10}$. Crucially, according to Davidson, triangulation is essential to there being mental content in the first place, in the sense that it is a metaphysically necessary condition for the acquisition of (contentful) thought. Consider, for example, the following passage:

Without this sharing of reactions to common stimuli, thought and speech would have no particular content— that is, no content at all. It takes two points of view to give a location to the cause of a thought, and thus to define its content. We may think of it as a form of triangulation: each of two people is reacting differentially to sensory stimuli streaming in from a certain direction. If we project the incoming lines outward, their intersection is the common cause. If the two people now note each other's reactions [....] each can correlate these observed reactions with his or her stimuli from the world. The common cause can now determine the contents of an utterance and a thought. The triangle which gives content to thought and speech is complete. But it takes two to triangulate. Two, or, of course, more ([30], pp. 159-60).

The idea that triangulation is metaphysically necessary for the acquisition of thought makes Davidson's view a form of content externalism, since it makes causal relationships to matters external to the subject necessary for thought. But this kind of content externalism is very different from the more familiar varieties defended in the literature. This is because the idea is not that particular kinds of contents, such as concerning a natural kind like water, should be conceived of along externalistic lines, but rather the more general thesis that there are external conditions for the acquisition of thought ${ }^{11}$.

In order to see how triangulation might be related to Davidson's views on radical interpretation and the principle of charity, consider this passage, which comes just after a discussion of how the principle of charity blocks radical skepticism:

What stands in the way of global skepticism of the senses is [...] the fact that we must, in the plainest and methodologically most basic cases, take the objects of a belief to be the causes of that belief. And what we, as interpreters, must take them to be is what they in fact are. Communication begins where causes converge: your belief means what mine does if belief in its truth is systematically caused by the same events and objects ([3], pp. 317-18).

Here we can see how the principle of charity, qua an indispensible ingredient in radical interpretation, is guiding an implicit commitment to triangulation. The connecting thought is that those cases where triangulation occurs are precisely the kind of 'plainest and methodologically most basic cases' in which we are required, following the principle of charity, to interpret a speaker so that she ends up speaking truly.

Moreover, notice the remark that 'what we, as interpreters, must take them [i.e., the objects of belief] to be is what they in fact are'. As he puts it elsewhere, commenting on the previous passage:

If anything is systematically causing certain experiences (or verbal responses), that is what the thoughts and utterances are about. This rules out systematic error. If nothing is systematically causing the experiences, there is no content to be mistaken about. To quote myself: "What stands in the way of global skepticism of

10 Note that the use of the, possibly intentional, notion of 'reacting to' may be controversial in this context, though for our purposes we think we can reasonably bracket such concerns in what follows.

11 A useful contrast here is between Davidson and the kind of content externalism famously proposed by Putnam (e.g., [33]).

For further discussion of content externalism, see [34]. 
the senses is [...] the fact that we must, in the plainest and methodologically most basic cases, take the objects of a belief to be the causes of that belief ([32], p. 199).

That we must interpret these utterances in the plainest and most basic cases as true is thus more than a methodological constraint on radical interpretation. Instead, Davidson's point is that these most basic cases effectively determine the contents of the relevant beliefs, so that there is no logical gap between what we as interpreters take the objects of a belief to be and the causes of that belief which could allow for the possibility of massive falsehood in one's beliefs. Here is Davidson:

[I]t cannot happen that most of our plainest beliefs about what exists in the world are false. The reason is that we do not first form concepts and then discover what they apply to; rather, in the basic cases the application determines the content of the concept ([3], p. 436).

Davidson is thus appealing to a form of externalism about mental content, whereby mental content can be determined, in part, by factors external to the subject. The idea is that the content of our thoughts and utterances is fixed, at least in part, by the social settings in which triangulation takes place. This is why the possibility of massive error in one's beliefs is impossible, contra the skeptic, and thus why 'belief is in its nature veridical'. For to suppose that this is possible is to suppose that the belief ascriptions offered in the 'plainest and methodologically most basic' cases of triangulation could be systematically false, and that claim is incompatible with Davidson's content externalism.

There are two points to note about this way of describing Davidson's anti-skepticism. The first is that at no point in setting out Davidson's position in this regard did we need to appeal to the notion of an omniscient interpreter. This reinforces the suggestion made earlier that it is really Davidson's content externalism, and his associated conception of triangulation, that is carrying the anti-skeptical load ${ }^{12}$.

The second point is that with Davidson's response to the radical skeptic set out this way it becomes much clearer why some have referred to it as a kind of transcendental argument. For the general style of the argument is to demonstrate on purely a priori grounds that there is a necessary condition for one even thinking a contentful thought—viz., that most of one's beliefs must be true. Since even the skeptic is committed to the possibility of there being contentful thought (as otherwise we could not even make sense of the skeptical enterprise, still less the specific skeptical appeal to radical error-possibilities, such as the scenario that one might be a BIV), so even the skeptic must accept the anti-skeptical consequences of this transcendental argument if it is sound. Indeed, if this transcendental argument is sound, then one can never even coherently expound radical skepticism ${ }^{13}$.

Understanding that Davidson is offering a transcendental response to the problem of skepticism explains why certain objections that have been made against his proposal fail to hit their target.

12 It is telling that Davidson's most subtle critics in this regard do not put any significant weight on Davidson's appeal to the notion of an omniscient interpreter, preferring instead to focus on his content externalism and his associated appeal to triangulation and the principle of charity. Stroud [25], for example, doesn't mention Davidson's appeal to the notion of an omniscient interpreter at all, while Williams [20] effectively only discusses the notion of an omniscient interpreter as an appendix to his discussion of the main Davidsonian line on radical skepticism. For a defence of the opposing view that the appeal to the notion of an omniscient interpreter is key to Davidson's anti-skepticism, see [35] and [36].

13 It is now quite common to interpret Davidson as offering a kind of transcendental argument against radical skepticism. See, for example, [35-37]; [38], ch. 19), and [39]. Davidson's anti-skepticism is also described as an 'exemplar' of a transcendental argument in ([40], §1). 
For example, Williams has argued that Davidson's response to the skeptical problem is in effect question-begging in that it presupposes that we have a kind of knowledge of the world which the skeptic would dispute. In particular, Williams charges Davidson with a subtle sleight of hand in his argument, by moving from the use of the principle of charity in the context of radical interpretation to applying that same principle in the context of the problem of radical skepticism. After all, in the former context we are using "our knowledge of the observable features of the world, taken as unproblematic, as the basis for determining referents for the alien speaker’s terms” ([10], p. 188). But once we start to appeal to the principle of charity to deal with the problem of radical skepticism this no longer makes sense, since none of our knowledge is in this context unproblematic. As Williams puts the point:

[...] the appeal to charity turns out to involve the idea of unproblematic access to certain causal relations between speakers and objects in the world. If, in the context of the sceptic's question, we grant ourselves this access, the game is over before it begins ([10], p. 188).

It should be clear that this is not a fair criticism of Davidson's anti-skepticism, at least once we understand that this anti-skepticism is transcendental in form. To begin with, note that Davidson isn't presupposing that we have any particular empirical knowledge of instances of triangulation as part of his argument against radical skepticism, but rather arguing, on entirely a priori grounds, that such triangulation is metaphysically necessary for contentful thought. If one cannot appeal to a priori considerations in dealing with the problem of radical skepticism, then obviously all philosophical responses to this problem are excluded.

But the mistake in Williams's reasoning runs deeper. We have noted above that Davidson's style of argument is transcendental, in the sense that he is demonstrating that from commitments that even the skeptic has we can derive anti-skeptical conclusions. One of the commitments which even the skeptic has is the idea that we are able to think contentful thoughts, since otherwise the skeptical doubt would be itself without content. We have just noted that Davidson argues on purely a priori grounds that triangulation is a metaphysically necessary condition for contentful thought. The upshot is that even the skeptic can be taken to be committed to triangulation, and all that comes with it, such as the instances of interpretation that occur in particular cases of triangulation. There is thus no begging of the question here. It is not as if Davidson is presupposing something contentious from the skeptic's point of view and then using it to undermine radical skepticism. Instead, the style of argument is simply to show that the skeptic herself has metaphysical commitments which are incompatible with her avowed skepticism ${ }^{14}$.

\section{The Rorty-Williams Debate Reevaluated}

Let us now return to the dispute between Rorty and Williams. Recall that Rorty maintains, contra Williams, that Davidson is offering a theoretical diagnosis of the problem the external world (one that rivals Williams’ own diagnosis). In particular, Rorty maintains that Davidson, like Williams, is not attempting to offer a direct response to the skeptical problem (i.e., one which accepts the theoretical presuppositions of that problem), but rather trying to demonstrate that the skeptical problem trades on dubious and illicit theoretical presuppositions which should be rejected.

\footnotetext{
14 For a recent survey article on Davidson's response to the problem of radical skepticism, see [12].
} 
In contrast, Williams is insistent that Davidson is putting forward a very different kind of anti-skepticism to his own, one that does indeed aim to meet the problem head-on. In favour of this reading, Williams writes that:

After all, an essential lemma in any sceptical argument is that all our beliefs, or all our beliefs in some wide domain, could be false. But Davidson argues that conceptual connections between the ideas of belief, truth and meaning show that this could not be so. Sceptical arguments necessarily fail because belief is essentially veridical. This certainly looks like an attempt to meet the sceptic head on. ([2], p. 34)

But this does not show that Davidson was attempting to meet the skeptic head on. Williams does not appreciate the point that Davidson has challenged a certain kind of "dualism" - the dualism between "scheme-and-content" (cf. [41]). How does this point bear on whether or not Davidson is providing a theoretical diagnosis of the problem of the external world?

At this point, it is useful to return to Stroud. In his later work, Stroud thinks that there is epistemological promise in Davidson's content externalism. The idea is this. When faced with the problem of the external world, we take it that the problem is to explain how we could ever know that our beliefs about the world around us are true, if it is also possible that we could be dreaming, or otherwise have all of the experiences we've ever had, compatible with all of our beliefs about the world being false. But Davidson's point is not just that it's not possible that we could have all of the beliefs that we have, while all of them are false. Instead, his point is that it's not possible for us to both identify all of our beliefs about the world, while at that same time be unable to know the causes of those beliefs - that is, know what those beliefs are about, and so be in a position to know that the beliefs are true. As we can see, if this is right, the challenge posed by the problem of the external world is undermined. It's not a direct refutation of skepticism about the external world-far from it. Instead, it's an undermining move: it prevents the epistemological problem from arising, where the question "how is knowledge of the world around us even possible?" becomes a pressing one.

Rorty is sensitive to this very point. Indeed, he says that:

If Davidson were, as Williams thinks he is, offering a direct answer to the sceptic, then indeed he would not be able to invoke such unproblematic access. But Davidson is not doing that. Rather, he is trying to undermine the sceptic's idea that we can know what our beliefs are without already having a lot of true beliefs about the causal relations between those beliefs and the world ([1], p. 6, emphasis added).

So, as far as Rorty is concerned, Davidson is not providing a direct response to the problem of the external world and its attendant skepticism. Instead, he is undermining the problem with his distinctive brand of content externalism. So this makes room for the idea that Davidson can provide a theoretical diagnosis of the problem of the external world—a diagnosis which tells us what philosophical theses ground that problem.

On this point, Rorty thinks not only could Davidson provide a theoretical diagnosis of the problem, but that he actually does:

This diagnosis says that the reason the sceptic thinks she needs an inference from experience to the world is that she does not understand that ascription of experience to herself requires ascribing intentional states, and that that is only possible for somebody who has a lot of true beliefs about the world. There is no such thing as knowing what you believe without knowing a lot about the objects of your belief ([1], p. 6). 
Here, the focus should not be on Davidson's view that we cannot know what we believe without knowing a lot about the causes of those beliefs, or be in a position to know a lot about the objects of those beliefs. Rather, the focus should be on the diagnostic element that "the reason the sceptic thinks she needs an inference from experience to the world is that she does not understand that ascription of experience to herself requires ascribing intentional states.” ([1], p. 6) Rorty's suggestion is that, if Davidson's content externalism is true, then it looks like the skeptic loses her reason for thinking that one needs an inference from experience to the world in order to explain how knowledge of the world is possible. The diagnosis here is that a would-be skeptic is working within a content internalist framework, and that without some such framework, the epistemological problem of the world cannot be generated.

It should be noted at this juncture that Rorty's reading of Davidson's anti-skepticism is very much in keeping with Davidson's own descriptions of his position in this regard, particularly in his later work. Consider, for example, this passage:

Reflecting on the nature of thought and interpretation led me to a position which, if correct, entails that we have a basically sound view of the world around us. If so, there is no point in attempting, in addition, to show the sceptic wrong ([42], p. 163) ${ }^{15}$.

Here it is clear what role the appeal to content externalism plays in Davidson's anti-skepticism, such that it is meant to undermine a key theoretical presupposition inherent to the set-up of the skeptical problem. The anti-skeptical diagnosis that Davidson takes himself to be offering is theoretical and indirect, rather than direct.

Of course, this is not to claim that Davidson's content externalism is true; nor is it to claim that content internalism does not capture, in theoretical terms, a pre-theoretical picture of how we understand what we and what other people believe. All of that is contentious and up for further debate, which takes us back to the problem of metaepistemological skepticism posed by Stroud. The claim that we wish to defend here is that Rorty's view that Davidson can be understood to be (1) providing a thesis which undercuts the problem of the external world, and (2) that this thesis is diagnostic in character: it can be used to explain which contentious philosophical theses a would-be skeptic must operate with in order to generate a fully general epistemological problem of the external world.

We should now turn to the question of whether the reading of Davidson as providing a transcendental response to the problem of the external world, and Rorty's reading of Davidson as providing a theoretical diagnosis to the problem of the external, are in tension. Of course, transcendental arguments are normally taken to be aiming at direct refutations of skepticism. The conclusions of these arguments are supposed to be propositions which are either in direct contradiction with skepticism or else in direct contradiction with an essential premise of the skeptical argument. But whether or not all transcendental arguments aim at direct refutations of skepticism is a complex and contentious issue. Without additional argument, there is no implication from the fact that Davidson provides a transcendental argument against skepticism to claim that he is not or cannot be offering a theoretical diagnosis of problem as well. We have no reason to think the two are incompatible.

15 See also [43], which was itself in part a response to Rorty's [44] critique of Davidson's apparently more direct way of dealing with the sceptical problem in [3]. 
For example, consider a version of Davidson's transcendental argument which is 'modest' in character. An 'ambitious' transcendental argument moves from a premise about the psychological—such as that we have beliefs and experiences-and connecting premise that a necessary condition of the truth of that psychological premise is something non-psychological, such as that there are mind-independent objects, to the conclusion that there are mind-independent objects. The conclusion of this argument is supposed to be anti-skeptical, because it is conceded that we can know psychological propositions, and that we can know a priori what are necessary conditions of the truth of those psychological propositions. From this, it would follow that we can know non-psychological propositions - propositions describing the world around us, the very propositions skepticism denies that we can know. And if this were the goal of Davidson's argument, then it would seem that Rorty is wrong in attributing to Davidson the aim of showing what theoretical principles ground the problem of the external world.

But not all transcendental arguments need to have that structure. A 'modest' transcendental argument does not seek to establish propositions about the world around us, and so it does not seek to establish the denial of skepticism. Instead, it seeks to show what we must think, believe, or experience, if we are to think, believe, or have experiences at all ${ }^{16}$. If Davidson's content externalism is true, then a necessary condition of ascribing states with content to myself and others is a capacity to identify, and so to know, the causes of those states with content. If the content of those states are about an external world, then a necessary condition of ascribing states with content about the external world to myself and others is a capacity to identify, and so to know, that there are external things. Now, the problem of the external world asks how knowledge of the world around us is even possible - how it's possible for us to know that what we believe to be so in the wider-world is actually so. The negative skeptical answer to this question says that knowledge of the world isn't possible. We can never know that what we believe to be so about the external world is actually so.

But if Davidson's content externalism is true, then a necessary condition of our being able to do what this question is asking us to do- to consider all of our beliefs about the external world, on the one hand, and explain how we could ever come to know that any of them are true, on the other-is that we can know that some of them are true. In short: a necessary condition of a positive answer to the first half of the question is a positive answer to the second half of the question. And, of course, the second part of the question is unintelligible unless the first half gets a positive answer ${ }^{17}$.

Notice that this argument is modest in character because it does not establish the conclusion that skepticism is false - that we can know about the external world. Instead, all that it establishes is that either we cannot know what we believe, or that we even have beliefs, or that if we can, we can know about the external world. The anti-skeptical force of the conclusion lies in seeing that the epistemological problem of the external world is unintelligible unless the first half of that disjunction is

16 For more on the distinction between modest and ambitious transcendental arguments, see [45]. The distinction is, of course, rooted in Stroud's [46] famous critique of transcendental arguments. See also [40] for a helpful and up-to-date survey of the general topic of transcendental arguments.

17 Cf. ([47], p. 189). After having conceded that an 'ambitious' transcendental argument from Davidson would fail, Stroud argues that this would not prevent Davidson's content-externalism from having anti-skeptical consequences. 
true and that it gets a positive answer if the second half of the disjunction is true. In either case, the problem of the external world is disarmed ${ }^{18}$.

Insofar as theoretical diagnoses of the problem of the external world are not in tension with the more modest type of transcendental argument, there is no longer a good reason for thinking that, if Rorty is correct that Davidson was aiming for a theoretical diagnosis of the problem, then he could not also have been aiming for a transcendental argument from his content externalism. The two are not mutually exclusive ${ }^{19}$. The upshot is that in the debate between Rorty and Williams over Davidson's anti-skepticism, it is Rorty who was in the right.

\section{Acknowledgments}

Special thanks to Neil Gascoigne and two anonymous referees for comments on an earlier version. Thanks also to Kirk Ludwig for helpful comments on the discussion of Davidson's anti-skepticism.

\section{Conflict of Interest}

The authors declare no conflict of interest.

\section{References and Notes}

1. Richard Rorty. “Comments on Michael Williams’s Unnatural Doubts.” Journal of Philosophical Research 22 (1997): 1-10.

2. Michael Williams. "Still Unnatural: A Reply to Vogel and Rorty.” Journal of Philosophical Research 22 (1997): 29-39.

3. Donald Davidson. "A Coherence Theory of Truth and Knowledge.” In Kant oder Hegel? Edited by Dieter Henrich. Stuttgart: Klett-Cotta, 1983, 428-38.

4. Barry Stroud. The Significance of Philosophical Scepticism. Oxford: Oxford University Press, 1984.

5. Michael Williams. Unnatural Doubts: Epistemological Realism and the Basis of Scepticism. Oxford: Blackwell, 1991.

6. Barry Stroud. “Scepticism and the Senses.” European Journal of Philosophy 17 (2009): 559-70.

7. John Langshaw Austin. “Other Minds.” In Philosophical Papers. Edited by James Opie Urmson, Geoffrey Warnock. Oxford: Clarendon Press, 1961, 76-116.

18 A longer version of this paper would engage with Rorty's wider treatment of transcendental arguments, most notably in [48] and [49]. This earlier engagement with transcendental arguments on Rorty's part evidently informs his thinking about Davidson's anti-skepticism in [1]. In particular, Rorty clearly wants to resist the idea —as famously expounded in [46], for example (though not quite in these terms) - that transcendental arguments cannot, in virtue of being modest, be fully adequate theoretical dissolutions of the skeptical problem. For an excellent treatment of Rorty's views in this regard, see ([50], ch. 3).

19 Interestingly, what goes for Davidson in this regard arguably also applies to McDowell's very different response to the skeptical problem, which is also cast along broadly transcendental lines, although it would take us too far afield to explore this issue in detail here. See [51-53]. For sympathetic discussion of this anti-skeptical proposal, see [54,55]. For an unsympathetic discussion, see [56]. 
8. Barry Stroud. Understanding Human Knowledge: Philosophical Essays. Oxford: Oxford University Press, 2000.

9. Barry Stroud. "Skepticism and Epistemological Satisfaction.” Philosophers Past and Present: Selected Essays. Oxford: Oxford University Press, 2011.

10. Michael Williams. “Epistemological Realism and the Basis of.” Mind 97 (1988): 415-39.

11. Duncan Pritchard. "Recent Work on Radical Skepticism.” American Philosophical Quarterly 39 (2002): 215-57.

12. Duncan Pritchard. "Davidson on Radical Skepticism.” Blackwell Companion to Donald Davidson chapter 30. Edited by Ernest LePore, and Kirk Ludwig. Oxford: Blackwell, 2013.

13. Christopher Ranalli. "Skepticism, Invulnerability, and Epistemological Dissatisfaction." Metaphysics or Modernity? Edited by Christian Illies, and Christian Schaefer. Bamberg: Bamberg University Press, Forthcoming.

14. Willard Van Orman Quine. Word and Object. Cambridge: MIT Press, 1960.

15. Donald Davidson. Subjective, Intersubjective, Objective. Oxford: Oxford University Press, 2001.

16. Richard Grandy. "Reference, Meaning and Belief.” Journal of Philosophy 70 (1973): 439-52.

17. Colin McGinn. "Radical Interpretation and Epistemology." In Truth and Interpretation: Perspectives on the Philosophy of Donald Davidson. Edited by Ernest LePore. Oxford: Blackwell, 1986, Chapter 19.

18. Donald Davidson. “Thought and Talk.” In Mind and Language. Edited by Samuel Guttenplan. Oxford: Oxford University Press, 1975, 7-23.

19. Donald Davidson. "The Method of Truth in Metaphysics." Midwest Studies in Philosophy 2 (1977): 244-54.

20. Michael Williams. "Scepticism and Charity.” Ratio 1 (1988): 176-94.

21. Peter Klein. "Radical Interpretation and Global Scepticism." In Truth and Interpretation: Perspectives on the Philosophy of Donald Davidson. Edited by Ernest LePore. Oxford: Blackwell, 1986, 368-86.

22. Bruce Vermazen. “The Intelligibility of Massive Error.” Philosophical Quarterly 33 (1983): 69-74.

23. Kirk Ludwig. "Skepticism and Interpretation.” Philosophy and Phenomenological Research 52 (1992): 317-39.

24. Thomas Nagel. “Davidson's New Cogito.” In The Philosophy of Donald Davidson. Edited by L.E. Hahn. Chicago: Open Court, 1999, 195-206.

25. Barry Stroud. "Radical Interpretation and Philosophical Scepticism." In The Philosophy of Donald Davidson. Edited by L.E. Hahn. Chicago: Open Court, 1999, 131-61.

26. Donald Davidson. "Reply to A. C. Genova." In The Philosophy of Donald Davidson. Edited by L.E. Hahn. Chicago: Open Court, 1999, 192-94.

27. Richard Foley, and Richard Fumerton. “Davidson's Theism?” Philosophical Studies 48 (1985): 83-89.

28. Anthony Brueckner. “The Omniscient Interpreter Rides Again.” Analysis 51 (1991): 192-205.

29. Anthony Brueckner. "Skepticism and Semantic Externalism." In The Routledge Companion to Epistemology. Edited by Sven Bernecker and Duncan Pritchard. London: Routledge, 2010, Chapter 46. 
30. Donald Davidson. “Three Varieties of Knowledge.” In A. J. Ayer Memorial Essays. Edited by A.P. Griffiths. Cambridge: Cambridge University Press, 1991, 153-66.

31. Donald Davidson. "Knowing One’s Own Mind.” Proceedings and Addresses of the American Philosophical Association 61 (1987): 441-58.

32. Donald Davidson. “Epistemology Externalized.” Dialectica 45 (1991): 191-202.

33. Hilary Putnam. "The Meaning of 'Meaning'." Minnesota Studies in the Philosophy of Science 7 (1975): 131-93.

34. Jesper Kallestrup. Semantic Externalism. London: Routledge, 2011.

35. Anthony Genova. “The Very Idea of Massive Truth.” In The Philosophy of Donald Davidson. Edited by L.E. Hahn. Chicago: Open Court, 1999, 167-91.

36. Amber Carpenter. "Davidson's Transcendental Argumentation: Externalism, Interpretation, and the Veridicality of Belief." In From Kant to Davidson: Philosophy and the Idea of the Transcendental. Edited by Jeff Malpas. London: Routledge, 2003, 219-37.

37. William Maker. “Davidson's Transcendental Argument.” Philosophy and Phenomenological Research 51 (1991): 345-60.

38. Ernest LePore, and Kirk Ludwig. Donald Davidson: Meaning, Truth, Language, and Reality, Oxford: Oxford University Press, 2005.

39. Jason Bridges. “Davidson's Transcendental Externalism.” Philosophy and Phenomenological Research 73 (2006): 290-315.

40. Robert Stern. “Transcendental Arguments.” In Stanford Encyclopaedia of Philosophy. Edited by Edward Zalta. 2011. http://plato.stanford.edu/entries/transcendental-arguments/.

41. Donald Davidson. “On the Very Idea of a Conceptual Scheme.” Proceedings and Addresses of the American Philosophical Association 47 (1974): 5-20.

42. Donald Davidson. "Reply to Barry Stroud.” In The Philosophy of Donald Davidson. Edited by L.E. Hahn. Chicago: Open Court, 1999, 162-66.

43. Donald Davidson. “Afterthoughts, 1987.” In Reading Rorty: Critical Responses to Philosophy and the Mirror of Nature and Beyond. Edited by Alan Malichowski. Oxford: Blackwell, 1990, 136-68.

44. Richard Rorty. "Pragmatism, Davidson and Truth.” In Truth and Interpretation: Perspectives on the Philosophy of Donald Davidson. Edited by Ernest LePore. Oxford: Blackwell, 1986, 333-55.

45. Anthony Brueckner. "Modest Transcendental Arguments.” Philosophical Perspectives 10 (1996): 265-80.

46. Barry Stroud. “Transcendental Arguments.” Journal of Philosophy 65 (1968): 241-56.

47. Barry Stroud. "The Epistemological Promise of Externalism.” In The Externalist Challenge. Edited by Richard Schantz. Berlin: DeGruyter, 2004, 181-92.

48. Richard Rorty. "Verificationism and Transcendental Arguments.” Noûs 5 (1971): 3-14.

49. Richard Rorty. "Transcendental Arguments, Self-Reference, and Pragmatism.” In Transcendental Arguments and Science: Essays in Epistemology. Edited by P. Bieri, R.-P. Horstmann and L. Krüger. Dordrecht: Reidel, 1979, 77-103.

50. Neil Gascoigne. Richard Rorty. Cambridge: Polity, 2008.

51. John McDowell. Mind and World. Cambridge: Harvard University Press, 1994. 
52. John McDowell. "Knowledge and the Internal.” Philosophy and Phenomenological Research 55 (1995): 877-93.

53. John McDowell. "The Disjunctive Conception of Experience as Material for a Transcendental Argument.” In Disjunctivism: Perception, Action, Knowledge. Edited by Adrian Haddock and Fiona Macpherson. Oxford: Oxford University Press, 2008, Chapter 16.

54. Duncan Pritchard. "McDowellian Neo-Mooreanism.” In Disjunctivism: Perception, Action, Knowledge. Edited by Adrian Haddock and Fiona Macpherson. Oxford: Oxford University Press, 2008, 283-310.

55. Duncan Pritchard. Epistemological Disjunctivism. Oxford: Oxford University Press, 2012.

56. Crispin Wright. "Comment on John McDowell's 'The Disjunctive Conception of Experience as Material for a Transcendental Argument'.” In Disjunctivism: Perception, Action, Knowledge. Edited by Adrian Haddock and Fiona Macpherson. Oxford: Oxford University Press, 2008, 390-404.

(C) 2013 by the authors; licensee MDPI, Basel, Switzerland. This article is an open access article distributed under the terms and conditions of the Creative Commons Attribution license (http://creativecommons.org/licenses/by/3.0/). 